was not responsible when suffering from the fits, and was not safe to be at large. Guilty, but insane.-Winchester Assizes (the Lord Chief Justice), June 28th.Times, June 30th.

One of the numerous instances of crime committed by a man who ought not to have been at large.

\title{
ASYLUM NEWS.
}

The New Edinburge Asylum.-Competitive plans for the asplum to be erected by the Edinburgh District Lunacy Board were exhibited to the public during the week of the British Medical Association meeting. We have already indicated that the system of construction developed at Alt Scherbitz was adopted, and the architects who sent in plans have worked in strict accordance with instructions. Mr. Hippolyte J. Blanc has been successful in securing the first place in order of merit, and his designs are to be adopted with certain modifications in detail. We hope to give a full account of the completed plans at no distant date.

\section{QUEBEC MEDICO-PSYCHOLOGICAL SOCIETY.}

The physicians attached to the asylum of the province of Quebec have organised themselves into an Association for the advancement of the specialty. Dr. Vallée has been appointed president, Dr. Burgin vice-president, and Dr. Chagnon secretary. The first meeting of the society was held at the St. Jean de Dieu Asylum on July 14th, 1898, and we have been favoured with an account of the proceedings, which will find place in our next issue.

\section{CORRESPONDENCE.}

Prom Dr. Percy Smith.

In the Julv Number of the JoURNAL I notice on page 653 a statement reported as made by the Chairman of the meeting of the Northern and Midland Division, held at Cheadle on May 25th, to the effect that " every hospital had pensioned its superintendent on retirement." I think it is right to correct this statement and sav that no superintendent of Bethlem Hospital has ever received a pension. This has, however, not been the fault of the governing body, but owing to the fact that the superintendents have gone into other spheres of work, with the exception of Dr. Helps, who died while still superintendent.

\section{OBITUARY.}

Hexry Case, M.R.C.S.

We record, with regret, the death of Mr. Henry Case, at Folkestone, on the 15th of June. He had but recently retired from the office of medical superintendent of the Leavesden Asylum, which he had held since 1876. Born in 1843, and medically educated at the Middlesex Hospital, at which he held with credit the post of house surgeon, he became subsequently house surgeon to the West Herts Infirmary and to the Hampstead Smallpox Hospital, and assistant medical officer to the Leavesden Asylum, of which, on Dr. Claye Shaw's removal to Banstead, he was entrusted with the chief charge.

For upwards of twenty-one years he held this important appointment, and discharged with zeal and efficiency its onerous duties, maintaining throughout the best relations both with his colleagues and patients, and, despite the number of the latter, having an intimate knowledge of their cases, and himself directing their medical treatment. For some years, and until increasing work compelled his relinquishment of the office, he was also lecturer on poychological medicine at the Middlesex Hospital. 
In January of the present year ill-heslth necessitated his retirement from Leavesden, and his colleagues and the staff generally marked this event by a handsome presentation of plate. The committee, to whom he had rendered service for so large a portion of his life, voted him the insignificant perision of $£ 250$ a year, and added yet another proof of the need which exists in the service of our speciality for a fixed and liberal scale of statutory pensions which shall be assured as the complement of long and faithful service.

R. Battress Scholes, M.D.

Dr. Scholes, whose death is recently recorded, was an Australian by birth, but studied in Edinburgh, where he took the degrees of M.B. and C.M. in 1874 . He returned to Australia, and at once entered the service of the Government of New South Wales as assistant medical officer of the Hospital for the Insane at Para. matta, from which he was soon promoted to the superintendentship of Callan Park. In 1878, on the nomination of Dr. Manning, he was appninted superintendent of Goodna, near Brisbane, Queensland, and later on became Inspector of the Asylums at Ipswich and Towoomba, and at the Reception Houses at Rockhampton, Townsville, and elsewhere, which Dr. Scholes himself established on the same basis as those in New South Wales.

Dr. Scholes soon placed the Lunacy Department of Queensland on a proper footing, and under his advice and with his assistance the new Lunacy Act was drafted and submitted to Parliament. By his genial manners and his kindness of heart he won the love and respect of the patients and staff, and by his administrative ability the confidence of all classes of the community. For twenty yeurs under his guidance the Lunacy Department of Queensland has worked without internal friction and without trouble to the Government, and at the same time with ever-increasing efficiency. As medical superintendent, an altogether unique experience befell Dr. Scholes. During the floods (previously unequalled) which some seven or eight vears ago wrecked the city of Brisbane, destroyed its bridges, devastated its beautiful botanic gardens, and ruined thousands of the colonists, Dr. Scholes found himself with upwards of $\mathbf{3 0 0}$ male patients in all stages of their malady surrounded by water and in imminent danger. As the water rapidly rose it was found necessary to vacate all the lower floors, and before nightfall it was ascertained that the buildings were in danger and were indeed in parts crumbling away. By means of a boat, guided by ropes made of torn bedding, it became necessary to remove al the patients through the windows of the upper stories. Such as resisted or were maniacal or suicilal were rolled in blankets and placed like mummies under the thwarts of the boat, and by morning Dr. Scholes had the satisfaction of finding al his patients, with one solitary exception, and all his attendants in safety in the wards set apart for women, which stood on higher grourd. Dr. Scholes himself crossed the flood in the last trip made by the hoat, and then had to house his homeless flock in buildings already overcrowded with female patients. These buildings, though on high ground, were surrounded by water, but to them were attached kitchens, bakeries, and stores, from which the whole Asylum population were supplied until the flood subsided and communication with the outside world was again possible. The Government of Queensland has since that time taken steps to remove the lowlying buildings, but before this could be completed Dr. Scholes, on two subsequen occasions, found it necessary to nıake every preparation for the timely removal of the whole of the male patients. To the incessant work incidental to his position, to the special anxieties attending the danger due to floods, and to the worry involved in the re-organisation of the Asylum, may no doult be attributed Dr. Scholes' early and unexpected death, which took place from heart disease on July 8th.

The great flood left behind it much misery and destitution in the village of Goodna, where many of the staff of the Asylum resided. This Dr. Scholes did his best to meet, not only by active sympathy, but by such munificent donations from his private means 28 has left an abiding sense of gratitude and respect. By $\mathrm{Dr}$. Scholes' death the Government of Queensland has lost one of the most trusted, able, 
and talented of its public servants, and the insane of the colony their truest and best friend. Dr. Scholes leaves a wife and family.

\section{Avgustr Vorsin.}

The death of Dr. Auguste Voisin has been announced. He was physician to the Saltpêtrière, and was best known bỵ his writings on idiocy, hysteria, hypnotism, and allied subjects. Dr. Voisin wes nephew to Dr. Pélix Voisin, formerly physician to the Bicêtre, and early in life devoted himself to the study of mental diseases. In 1879 he won an appointment to the Bicêtre, which be held until 1884, when he was transferred to the Saltpêtrière as physician to the department of backward children and epileptics. Dr. Voisin's paper at the Bournemouth meeting of the British Medical Association (1891) directed special attention to his opinions on the relation of hypnotism to crime, for he held that his experiments had indubitably proved that persons in the hvpnotic condition might be caused to commit crime unconscious of the act. Dr. Voisin's treatment of insane persons by hypnotism did not command the approval of independent observers, and was not pursued by his colleagues.

\section{NOTICES BY THE REGISTRAR.}

The following gentlemen were successful at the examination for the Certificate in Poychological Medicine, held on July 7 th, 1898 :

Examined at Bethlem Hospital, London.-Herbert Barraclough, Frank Herbert A. Clayton, William Cotton.

Examined at the Royal Asylum, Morningside, Edinburgh.-James Masson, James Orr, William James Stuart, David Barty King.

'The following is a list of questions which appeared on the paper :

1. What indications with regard to a person's sanity or insanity may be obtained from observation of his or her dress? 2. To what points would you specially direct your attention with a view to ascertaining the testamentary capacity of a patient ? Can a patient in an asvlum make a valid will? 3. What are the principal svmptoms which distınguish a case of acute dementia or anergic stupor from one of melancholia attonita? 4. In what forms do climacteric insanity appear? Give the prognosis of each. 5. Deseribe the different kinds of mental disturbance that occur in epileptic insanity. State shortly the connection between epilepsy and crime. 6. Cornpare the various forms of auditory hallucination with the various forms of deafness of cerebral origin. Describe psycho-motor hallucinations.

The Bronze Medal has been awarded to John Robert Lord, M.B., C.M., Assistant Medical Officer, London Counts Asylum, Hanwell.

The next examination for the Certificate in Psycholngical Medicine will be held in December, 1898. Due notice of the date will appear in this Journal and in the medical papers.

Examination for the Nursing C'ertificate.-The next examination for the Certificate of Proficiency in Nursing will be held on Monday, November 7 th, 1898, and candidates are earnestly requested to send in their schedules, duly filled up, to the Registrar of the Association not later than Mondas, October 3rd, 1898, as that will be the last day upon which, under the rules, applications for examination can be received.

\section{Note.}

As the names of some of the persons to whom the Nursing Certificate has been granted by the Association have been removed from the Register, employers are requested to refer to the Registrar in order to ascertain if a particular name is still on the roll of the Association. In all inquiries the number of the Certificate should be given.

For further particulars respecting the various examinations of the Association, apply to the Registrar, Dr. Spence, Burntwood Asylum, near Lichfield. 